\title{
Management of Postoperative Spondylodiscitis with and without Internal Fixation
}

\section{Internal Fiksasyon ile veya Olmadan Postoperatif Spondilodiskit Tedarvisi}

\author{
Xiang WANG, Hairong TAO, Yanhui ZHU, Xiongwei LU, Xiaopeng HU \\ Shanghai 3rd People's Hospital, School of Medicine, Shanghai Jiao Tong University, Department of Orthopaedics, Shanghai, China
}

Corresponding Author: Hu XIAOPENG / E-mail: xiaopenghudoc@163.com

\begin{abstract}
Postoperative spondylodiscitis is relatively uncommon. This complication is associated with increased cost, and long-term of inability to work, and even morbidity. Although the majority of postoperative spondylodiscitis cases can be well managed by conservative treatment, postoperative spondylodiscitis after internal fixation and those cases that are unresponsive to the conservative treatment present challenges to the surgeon. Here, a review was done to analyze the treatment of postoperative spondylodiscitis with/without internal fixation. This review article suggested that majority of postoperative spondylodiscitis without internal fixation could be cured by conservative treatment. Either posterior or anterior debridement can be used to treat postoperative spondylodiscitis without internal fixation when conservative treatment fails. In addition, minimally invasive debridement and drainage may also be an alternative treatment. In case of postoperative spondylodiscitis after internal fixation, surgical treatment was required. In the cervical spine, it can be well managed by anterior debridement, removal of internal fixation, and reconstruction of the spinal stability by using bone grafting/cage/anterior plate. Postoperative spondylodiscitis after internal fixation is successfully managed by combined anterior debridement, fusion with posterior approach and removal of pedicle screw or extension of pedicle screw beyond the lesion site, in the thoracic and lumbar spine.
\end{abstract}

KEYWORDS: Anterior debridement, Conservative treatment, Internal fixation, Posterior debridement, Spondylodiscitis, Surgery

öz

Postoperatif spondilodiskit nispeten nadirdir. Bu komplikasyon, artmış maliyet ve uzun süreli çalışamama ve hatta morbidite ile ilişkilidir. Postoperatif spondilodiskit olgularının çoğu konservatif tedaviyle iyi takip edilebilir ama internal fiksasyondan sonra postoperatif spondilodiskit ve konservatif tedaviye cevap vermeyenler cerrah açısından zorluk çıkarırlar. Derleme internal fiksasyon ile veya olmadan postoperatif spondilodiskit tedavisinin analizini içermektedir ve internal fiksasyonsuz postoperatif spondilodiskit olgularının çoğunda konservatif tedaviyle tam başarı sağlanabileceğini düşündürmektedir. Konservatif tedavi başarısız olduğunda internal fiksasyonsuz postoperatif spondilodiskiti tedavi etmek için posterior veya anterior debridman kullanılabilir. Ayrıca minimal invaziv debridman ve drenaj da alternatif tedavi olabilir. Internal fiksasyon sonrasında postoperatif spondilodiskit durumunda cerrahi tedavi gereklidir. Servikal omurgada bu durum anterior debridman, internal fiksasyonun çıkarılması ve kemik greftleri/kafesi/anterior plak kullanımıyla spinal stabilite-rekonstrüksiyon yoluyla iyi bir şekilde tedavi edilebilir. İnternal fiksasyon sonrasında postoperatif spondilodiskit durumu kombine anterior debridman, posterior yaklaşımla füzyon ve torasik ve lomber omurgada pedikül vidasının lezyon bölgesinin ötesine uzatılması veya pedikül vidasının çıkarılması ile başarılı bir şekilde tedavi edilebilir.

ANAHTAR SÖZCÜKLER: Anterior debridman, Konservatif tedavi, İnternal fiksasyon, Posterior debridman, Spondilodiskit, Cerrahi

\section{INTRODUCTION}

Postoperative spondylodiscitis is relatively uncommon. Most cases of postoperative spondylodiscitis are characterized by recurrent severe back pain and low fever after the initial spinal surgery $(16,32,39)$. An elevated erythrocyte sedimentation rate (ESR) and C-reactive protein (CRP) level is often demonstrated (20). Both of them are useful for early diagnosis of postoperative spondylodiscitis. Specially, CRP has been proved to be a sensitive indicator of the presence of postoperative spondylodiscitis (33). The X-ray and CT scan may indicate disc height loss and defect of the vertebral body at the late stage of spondylodiscitis (38). Therefore, X-ray and CT scan are rarely useful to detect the early infections. MRI has been shown to be the most useful study to diagnose postoperative spondylodiscitis, especially in the early stage of the infection $(6,47)$. The infected disc space appears as hypointense signals on T1- and hyperintense signals on T2weighted MR images $(42,45)$. Based on the above clinical presentation, laboratory parameters, and radiological imaging, and the spinal operation history, the primary diagnosis of postoperative spondylodiscitis is not difficult for the spinal surgeon, at present. The objective of this article was to review the management of postoperative spondylodiscitis with/without internal fixation.

\section{Conservative Treatment}

Conservative treatment for postoperative spondylodiscitis without internal fixation

The conservative treatment of spondylodiscitis includes antibiotic therapy and immobilization such as bed rest and 
spinal bracing. Once spondylodiscitis is diagnosed, patients are managed by empirical continuous intravenous broadspectrum antibiotic and immobilization. Percutaneous biopsy of the affected vertebral bodies under CT monitoring was advised to determine the efficacy and safety of the antibiotics $(13,34)$. Antibiotics are adjusted to the sensitivities of these organisms according to the percutaneous biopsy results. In the series reported by Bettini et al., 56 patients with primary pyogenic spinal infection were successfully managed by antibiotic therapy and spinal bracing (5). In another series reported by Valancius et al., 91 cases of primary spondylodiscitis were managed conservatively. They concluded that conservative therapy is safe and effective for carefully selected patients without spondylodiscitic complications (44). Regarding the treatment of postoperative spondylodiscitis without internal fixation, Kutlay et al., (27) reported 22 cases treated with antibiotics and hyperbaric oxygen therapy. The results indicated that all 22 patients were successfully treated without recurrence. In the recent study of Basu, 17 cases of postoperative discitis were treated with rest and antibiotic therapy alone and 13 cases responded well to the conservative therapy (2). Postacchini and Cinotti reported 13 cases where postoperative spondylodiscitis was treated by antibiotics in 6 cases. Antibitiocs were started at 31 days postoperatively on average and continued for 62 days, and symptoms were relieved after 3.9 months. At the final followup, X-ray indicated moderate changes of vertebral bodies in 4 cases and extensive osteolytic lesions of vertebral bodies in 2 cases. In the other 7 cases, antibiotics were initiated a mean of 8 days postoperatively and symptoms were relieved after 1.8 months without marked destructive lesions of the vertebral bodies. They concluded that the course of postoperative spondylodiscitis could be shortened by early and adequately prolonged antibiotic treatment. Extensive vertebral body lesions could also be avoided (37). Based on the above reports, antibiotics and bed rest are an effective treatment for the majority of the postoperative spondylodiscitis cases without internal fixation. Early and adequately effective antibiotic treatment can control spread of the infection and avoid the development of vertebral body lesions when early diagnosis is confirmed.

\section{Conservative treatment for postoperative spondylodiscitis after} internal fixation

Conservative treatment may not suitable for postoperative spondylodiscitis after internal fixation. There are several reports describing the management of postoperative spondylodiscitis after internal fixation. All the reports advocate radical debridement, removal of the internal fixation/extension of internal fixation beyond the lesion site, and fusion of the infected spinal segment for the treatment of postoperative spondylodiscitis after internal fixation.

\section{Surgical Treatment}

Surgical treatment for postoperative spondylodiscitis without internal fixation
For postoperative spondylodiscitis without internal fixation, operative management has been recommended when conservative treatment has failed $(1,20)$. Posterior debridement and fusion with/without instrumentation is widely used for spontaneous infectious spondylodiscitis $(12,17,22,48)$ since most spinal surgeons are familiar with the posterior operative approach. Several studies have reported that spontaneous infectious spondylodiscitis and septic hematogenous spondylodiscitis were successfully treated with posterior debridement and fusion with/without stabilization $(12,17,22,48)$ but there are only a few articles describing posterior debridement for the treatment of postoperative spondylodiscitis without internal fixation. In 2012, a retrospective study of 35 cases of postoperative spondylodiscitis without internal fixation was published where 29 patients who were unresponsive to conservative treatment were treated by posterior debridement and none of the cases required anterior fusion. Internal fixation was also not required. Within nine months follow-up, all patients recovered fully without disability or neurological deficit (20).

The infectious and necrotic tissues were mainly limited to the diseased intervertebral disc in the majority of the patients with pyogenic spondylodiscitis. Additionally, the posterior spinal structures were not greatly affected. Some of the recent reports indicated that anterior spinal surgical approach could radically debride the infectious and necrotic tissue of the diseased intervertebral disc under direct visualization (9, 10). There are also reports of spondylodiscitis/pyogenic vertebral osteomyelitis being treated by anterior debridement and fusion with/without anterior instrumentation $(8,9,11$, 14). Additionally, anterior debridement combined with onestage/staged posterior internal fixation has been used to treat patients with primary pyogenic vertebral osteomyelitis (10, $15,36,40,43)$. There are few studies on anterior debridement for the treatment of postoperative spondylodiscitis, however. In the case reported by Ahn and Lee (1), 6 cases of postoperative spondylodiscitis after transforaminal percutaneous endoscopic lumbar discectomy, who were unresponsive to the extensive antibiotic therapy or surgical drainage, were treated by anterior lumbar interbody fusion with posterior instrumentation. The modified MacNab criteria results were good in 3 patients, fair in 2 patients and poor in one patient within 20 to 48 months of follow-up.

There are reports on surgical treatment other than open surgery for postoperative spondylodiscitis without internal fixation when conservative treatment has failed. In a retrospective case series analysis, Bavinzski et al., (4) reported 17 cases of septic postoperative spondylodiscitis without internal fixation treated by microsurgical debridement and application of a closed suction-irrigation system supported by specific antibiotic therapy. During the operation, all the patients were managed by the same microsurgical approach to remove the necrotic and infected tissue. The infected disc space was then extensively irrigated by normal saline, diluted povidone/iodine solution, and hydrogen peroxide. Finally, a closed vacuum suction-irrigation drainage system 
Table I: Data of the Management of Postoperative Spondylodiscitis After Internal Fixation in the Cervical Spine

\begin{tabular}{|l|l|l|l|l|l}
\hline Study & Design & Operative approach & Initial internal fixation & $\begin{array}{l}\text { Cervical spine } \\
\text { reconstruction }\end{array}$ \\
\hline Kulkami and Hee (26) & Case report & Anterior debridement & $\begin{array}{l}\text { Anterior plate removed, } \\
\text { cage left in place }\end{array}$ & Autograft \\
\hline $\begin{array}{l}\text { Basu and } \\
\text { Sreeramalingam (3) }\end{array}$ & Case report & Anterior debridement & Removed & $\begin{array}{l}\text { Autograft and } \\
\text { anterior plate }\end{array}$ \\
\hline Korovessis et al. (25) & Case report & Anterior debridement & $\begin{array}{l}\text { Cage removed, posterior } \\
\text { instrumentation left in } \\
\text { place }\end{array}$ & Cage with autograft & Fusion \\
\hline
\end{tabular}

Table II: Data of the Management of Postoperative Spondylodiscitis After Internal Fixation in the Thoracic and Lumbar Spine

\begin{tabular}{|c|c|c|c|c|c|}
\hline Study & Design & Operative approach & Initial internal fixation & $\begin{array}{l}\text { Thoracic and } \\
\text { lumbar spine } \\
\text { reconstruction }\end{array}$ & Outcome \\
\hline $\begin{array}{l}\text { Carmouche and } \\
\text { Molinari (7) }\end{array}$ & Case report & Not clear & Removed & $\begin{array}{l}\text { Posterolateral } \\
\text { autograft }\end{array}$ & Fusion \\
\hline Neumayer et al. (35) & Case report & $\begin{array}{l}\text { Posterior and second- } \\
\text { stage anterior } \\
\text { debridement }\end{array}$ & Removed & $\begin{array}{l}\text { Anterior autograft } \\
\text { and instrumentation }\end{array}$ & Fusion \\
\hline Lange et al. (28) & Case report & $\begin{array}{l}\text { Repeat anterior } \\
\text { debridement } \\
\text { and posterior } \\
\text { instrumentation } \\
\text { extension }\end{array}$ & Left in place & $\begin{array}{l}\text { Cage with autograft } \\
\text { and posterior } \\
\text { instrumentation }\end{array}$ & Fusion \\
\hline Hsieh et al. (23) & Case series & $\begin{array}{l}\text { Posterior and first-/ } \\
\text { second-stage anterior } \\
\text { debridement }\end{array}$ & $\begin{array}{l}9 \text { Removed } \\
2 \text { Left in place }\end{array}$ & $\begin{array}{l}\text { Anterior autograft } \\
\text { Posterior } \\
\text { instrumentation } \\
\text { for } 2\end{array}$ & Fusion \\
\hline
\end{tabular}

was inserted in the infected disc space. The rate of irrigation was maintained at $30-50 \mathrm{ml} / \mathrm{h}$ without antibiotics in the solution. Systemic intravenous antibiotics were used 3-4 weeks, followed by oral antibiotics for 2-3 months. All the patients became pain-free 2-4 weeks postoperatively and 14 of the 17 patients obtained good to excellent results. MRI examinations confirmed resolution of the infectious processes in 16 of the patients except one patient where MRI was not performed due to a metal implant. In the series of 34 patients of Li et al., (29), all the patients with postoperative spondylodiscitis without internal fixation were treated by percutaneous discectomy and drainage. There were 31 cases of postoperative lumbar spondylodiscitis and 3 cases of postoperative cervical spondylodiscitis. Immediate relief of back pain was reported by 25 patients after this operative procedure. All cervical patients had pain improvement within $24 \mathrm{~h}$ and the condition improved within the first week after the operative procedure. They monitored 31 cases from 2 to 10 years and they concluded this procedure was an invasive procedure for obtaining biopsy material for histological analysis and culture. In addition, this operative procedure had a good clinical outcome.
Although the use of anterior or posterior debridement for the treatment of spondylodiscitis remains controversial, patients with postoperative spondylodiscitis who were unresponsive to conservative treatment can be successfully managed either with posterior or anterior debridement based on the literature. Moreover, minimally invasive debridement and drainage may be also an alternative treatment for postoperative spondylodiscitis when conservative management has failed, especially in elderly patients and patients in poor condition.

Surgical treatment for postoperative spondylodiscitis after internal fixation

For the treatment of postoperative spondylodiscitis after internal fixation, the few published reports unanimously agree that operative procedures are required. In the cervical spine, three reports have described the management of postoperative spondylodiscitis after internal fixation (Table I). In 2006, Kulkarni and Hee (26) described a 56-year-old male patient who presented with $\mathrm{C} 4 / 5$ spondylodiscitis occurring adjacent to $C 5 / 6$ and C6/7 levels for which anterior cervical discectomy and fusion using PEEK cages and plating was performed. This patient underwent debridement, 
decompression of the $C 4 / 5$ spinal cord, and removal of the plate and screws. The cages were left intact, and the C4/5 level was reconstructed with tricortical iliac crest autograft. The X-rays confirmed solid fusion of $\mathrm{C} 4 / 5, \mathrm{C} 5 / 6$, and C6/7 five months postoperatively. In 2012, Basu and Sreeramalingam (3) described another case of adjacent spondylodiscitis (C3/4) after anterior cervical decompression and fusion from $\mathrm{C} 5$ to C7 was performed in a 39-year-old male patient. Anterior debridement/decompression of the C3/4 disc space and removal of internal fixation were performed. Afterwards, C3/4 was fused by using iliac crest bone grafting and anterior plate. At the final follow-up, he had completely recovered and gone back to work. Additionally, X-rays confirmed good fusion from C2 to C7 without signs of recurrence of infection. In 2012, Korovessis et al., (25). reported a case of cervical spondylodiscitis associated with oesophageal perforation after combined staged posterior (lateral mass screws) and anterior (plate, PEEK) fusion for $\mathrm{C} 5 / 6$ fracture dislocation. This patient also underwent debridement, removal of the anterior spinal implants, and a mesh cage with iliac bone graft was inserted into the $\mathrm{C} 5 / 6$ disc space. The esophagus posterior wall was fixed with sutures. Successful fusion was obtained between $\mathrm{C} 5 / 6$ without infection recurrence at the final followup. Based on the review of above articles, postoperative spondylodiscitis after internal fixation in the cervical spine can be well managed by radical anterior debridement, removal of internal fixation at the lesion site, and reconstruction of cervical spinal stability by using bone grafting with/without cage and/or anterior plate.

In the thoracic and lumbar spine, several studies had described the management of postoperative spondylodiscitis after internal fixation (Table II). The first report in postoperative spondylodiscitis after internal fixation was published by Carmouche and Molinari (7), they reported a 35-year-old male patient with a diagnosis of epidural abscess and discitis at the $L 4 / 5$ level after instrumented posterior lumbar interbody fusion using a single carbon fiber interbody cage. Surgical debridement and epidural abscess drainage were performed. However, his clinical symptoms, ESR and CRP levels were not improved and became even worse. Repeat debridement was performed, and his interbody cage and pedicle screw instrumentation were removed. Six months postoperatively, X-ray demonstrated solid bilateral posterolateral arthrodesis of $L 4 / 5$ and the clinical symptoms were reduced at the final follow-up. Although the details pertaining to the operative approach in this case is lacking, it is apparently important to remove the internal fixation at the infection site. In 2009, Neumayer, F reported a case of T12/L1 postoperative spondylodiscitis after internal fixation due to a multiresistant organism. The infection was controlled by anterior debridement, anterior internal fixation, and 12 months of intravenous antibiotic treatment. At the final follow-up, spinal fusion was achieved. Moreover, reoccurrence of infection was not noted (35). In 2010, Lange et al., (28) reported a 70-yearold woman suffering from $\mathrm{L} 1 / 2$ spondylodiscitis initially. After surgical intervention with posterior stabilization, debridement, and replacement of the $L 1 / 2$ vertebral bodies, adjacent spondylodiscitis at T10/11 was diagnosed 2 months postoperatively. Removal of the vertebral body of T11 and extension of posterior instrumentation were carried out. However, repeated spinal radiographs and MRI indicated an adjacent spondylodiscitis at the T8/9 level 14 months later. Removal of the vertebral bodies of T8 and T9 was carried out and the posterior stabilization was extended up to T5. At the last follow-up, clinical examination, blood testing, and radiograph suggested no evidence of any further spondylodiscitis.

The first series describing postoperative spondylodiscitis after internal fixation was reported by Hsieh et al., (23) in 2011. He reported 11 patients diagnosed with postoperative spondylodiscitis after posterior pedicle screw instrumentation for 10 cases of degenerative lumbar disease and a case of osteoporotic spine fracture. For the treatment of spondylodiscitis, internal fixation was removed in 9 patients who had concomitant posterior infection. The posterior pedicle screw was extended beyond the lesion site in the other 2 patients without posterior infection who had confirmed pseudarthrosis. In these 11 patients, 6 cases were treated by posterior debridement and removal of instrumentation, and one-stage anterior debridement and fusion. Staged anterior debridement and fusion were performed for the other 5 cases after the first staged posterior surgery. At the final followup, the 11 patients were all successfully treated by removal of instrumentation/extension of instrumentation beyond the lesion site, and one-stage/staged anterior debridement and fusion. As it is well known, anterior debridement can radically remove infectious and necrotic tissue in the disc space under direct visualization. Extension of the pedicle screw can provide immediate spinal stability, which is helpful in the healing process of the infection. Taken together, postoperative spondylodiscitis after internal fixation can be successfully managed by combined anterior debridement and fusion with a posterior approach removal of pedicle screw if spinal fusion is obtained, or extension of the pedicle screw beyond the lesion site if spinal fusion is not obtained, in the thoracic and lumbar spine.

\section{Prevention}

Due to the increase in spinal surgery, postoperative spondylodiscitis has been recently reported as an increasing complication of such surgery $(19,21,24,30,46)$. Careful intraoperative technique, irrigation of the incision, and perioperative/intraoperative antibiotics are recommended for the prophylaxis of postoperative spondylodiscitis. To prevent postoperative spondylodiscitis, appropriate use of antibiotics is the most important prophylaxis. Some reports argue that perioperative antibiotics can effectively prevent postoperative spondylodiscitis $(18,49)$. Others believe that intraoperative antibiotic prophylaxis is effective to prevent postoperative spondylodiscitis after spinal surgery. Additionally, postoperative prophylaxis is not adopted or significantly reduced $(30,31)$. A retrospective study reported that placement of gentamicin-containing collagenous 
sponges in the disc space were effective in preventing postoperative spondylodiscitis (41).

In summary, preoperative/intraoperative antibiotics can effectively prevent the postoperative spondylodiscitis after spinal surgery because it is considered that prophylactic antibiotics can eliminate bacteria that are iatrogenically inoculated into the disc space during the operation. The local use of antibiotics is effective in preventing postoperative spondylodiscitis as well, although there are few reports.

\section{CONCLUSION}

Once the primary diagnosis is confirmed, early and adequately prolonged antibiotic treatment is recommended. The majority of the postoperative spondylodiscitis without internal fixation cases can be successfully treated by conservative treatment. Either posterior or anterior debridement can be used to treat postoperative spondylodiscitis without internal fixation when it is unresponsive to conservative treatment. Minimally invasive debridement and drainage may also be an alternative treatment. Surgical treatment was required for postoperative spondylodiscitis after internal fixation. In the cervical spine, it can be well managed by anterior debridement, removal of internal fixation, and reconstruction of the spinal stability by using bone grafting/cage/anterior plate. In the thoracic and lumbar spine, it can be successfully managed by combined anterior debridement and fusion with posterior approach removal of pedicle screw or extension of pedicle screw beyond the lesion site. In conclusion, the morbidity and the serious complications of postoperative spondylodiscitis can be decreased with early diagnosis and proper treatment.

\section{ACKNOWLEDGMENTS}

This work is supported by the National Natural Science Foundation of China (81101380)in the manuscript.

\section{REFERENCES}

1. Ahn $\mathrm{Y}$, Lee $\mathrm{SH}$ : Postoperative spondylodiscitis following transforaminal percutaneous endoscopic lumbar discectomy: Clinical characteristics and preventive strategies. $\mathrm{Br} J$ Neurosurg 26(4):482-486,2012

2. Basu S, Ghosh JD, Malik FH, Tikoo A: Postoperative discitis following single-level lumbar discectomy: Our experience of 17 cases. Indian J Orthop 46(4):427-433,2012

3. Basu S, Sreeramalingam R: Adjacent level spondylodiscitis after anterior cervical decompression and fusion. Indian J Orthop 46(3):360-363,2012

4. Bavinzski G, Schoeggl A, Trattnig S, Standhardt $H$, Dietrich W, Reddy M, Al-Schameri R, Horaczek A: Microsurgical management of postoperative disc space infection. Neurosurg Rev 26(2):102-107,2003

5. Bettini N, Girardo M, Dema E, Cervellati S: Evaluation of conservative treatment of non specific spondylodiscitis. Eur Spine J 18 Suppl 1:143-150,2009
6. Boden SD, Davis DO, Dina TS, Sunner JL, Wiesel SW: Postoperative diskitis: Distinguishing early MR imaging findings from normal postoperative disk space changes. Radiology 184(3):765-771,1992

7. Carmouche JJ, Molinari RW: Epidural abscess and discitis complicating instrumented posterior lumbar interbody fusion: A case report. Spine (Phila Pa 1976) 29(23):E542546,2004

8. D'Aliberti G, Talamonti G, Villa F, Debernardi A: The anterior stand-alone approach (ASAA) during the acute phase of spondylodiscitis: Results in 40 consecutively treated patients. Eur Spine J 21 Suppl 1:S75-82,2012

9. Dai LY, Chen WH, Jiang LS: Anterior instrumentation for the treatment of pyogenic vertebral osteomyelitis of thoracic and lumbar spine. Eur Spine J 17(8):1027-1034,2008

10. Dimar JR, Carreon LY, Glassman SD, Campbell MJ, Hartman MJ, Johnson JR: Treatment of pyogenic vertebral osteomyelitis with anterior debridement and fusion followed by delayed posterior spinal fusion. Spine (Phila Pa 1976) 29(3):326-332; discussion 332,2004

11. Emery SE, Chan DP, Woodward HR: Treatment of hematogenous pyogenic vertebral osteomyelitis with anterior debridement and primary bone grafting. Spine (Phila Pa 1976) 14(3):284-291,1989

12. Endres S, Wilke A: Posterior interbody grafting and instrumentation for spondylodiscitis. J Orthop Surg (Hong Kong) 20(1):1-6,2012

13. Enoch DA, Cargill JS, Laing R, Herbert S, Corrah TW, Brown NM: Value of CT-guided biopsy in the diagnosis of septic discitis. J Clin Pathol 61(6):750-753,2008

14. Fang D, Cheung KM, Dos Remedios ID, Lee YK, Leong JC: Pyogenic vertebral osteomyelitis: Treatment by anterior spinal debridement and fusion. J Spinal Disord 7(2): 173-180,1994

15. Fayazi AH, Ludwig SC, Dabbah M, Bryan Butler R, Gelb DE: Preliminary results of staged anterior debridement and reconstruction using titanium mesh cages in the treatment of thoracolumbar vertebral osteomyelitis. Spine J 4(4):388395,2004

16. Fernand R, Lee CK: Postlaminectomy disc space infection. A review of the literature and a report of three cases. Clin Orthop Relat Res 209:215-218,1986

17. Gonzalvo A, Abdulla I, Riazi A, De La Harpe D: Single-level/ single-stage debridement and posterior instrumented fusion in the treatment of spontaneous pyogenic osteomyelitis/ discitis: Long-term functional outcome and health-related quality of life. J Spinal Disord Tech 24(2):110-115,2011

18. Guiboux JP, Cantor JB, Small SD, Zervos M, Herkowitz HN: The effect of prophylactic antibiotics on iatrogenic intervertebral disc infections. A rabbit model. Spine (Phila Pa 1976) 20(6):685-688,1995

19. Hadjipavlou AG, Gaitanis IN, Papadopoulos CA, Katonis PG, Kontakis GM: Serratia spondylodiscitis after elective lumbar spine surgery: A report of two cases. Spine (Phila Pa 1976) 27(23):E507-512,2002 
20. Hamdan TA: Postoperative disc space infection after discectomy: A report on thirty-five patients. Int Orthop 36(2):445-450,2012

21. Han IH, Kim KS, Park HC, Chin DK, Jin BH, Yoon YS, Ahn JY, Cho $\mathrm{YE}$, Kuh SU: Spinal surgery in patients with end-stage renal disease undergoing hemodialysis therapy. Spine (Phila Pa 1976) 34(18):1990-1994,2009

22. Hempelmann RG, Mater E, Schon R: Septic hematogenous lumbar spondylodiscitis in elderly patients with multiple risk factors: Efficacy of posterior stabilization and interbody fusion with iliac crest bone graft. Eur Spine J 19(10):17201727,2010

23. Hsieh MK, Chen LH, Niu CC, Fu TS, Lai PL, Chen WJ: Postoperative anterior spondylodiscitis after posterior pedicle screw instrumentation. Spine J 11(1):24-29,2011

24. Jhala A, Mistry M: Endoscopic lumbar discectomy: Experience of first 100 cases. Indian J Orthop 44(2):184-190,2010

25. Korovessis P, Repantis T, Vitsas V, Vardakastanis K: Cervical spondylodiscitis associated with oesophageal perforation: $A$ rare complication after anterior cervical fusion. Eur J Orthop Surg Traumatol 23 Suppl 2:S159-163,2013

26. Kulkarni AG, Hee HT: Adjacent level discitis after anterior cervical discectomy and fusion (ACDF): A case report. Eur Spine J 15 Suppl 5:559-563,2006

27. Kutlay M, Colak A, Simsek H, Yildiz S, Topuz K, Kaya S, Cetinkal A, Demircan M: Antibiotic and hyperbaric oxygen therapy in the management of post-operative discitis. Undersea Hyperb Med 35(6):427-440,2008

28. Lange T, Schulte TL, Bullmann V: Two recurrences of adjacent spondylodiscitis after initial surgical intervention with posterior stabilization, debridement, and reconstruction of the anterior column in a patient with spondylodiscitis: A case report. Spine (Phila Pa 1976) 35(16):E804-810,2010

29. Li J, Yan D, Duan L, Zhang Z, Zhu H: Percutaneous discectomy and drainage for postoperative intervertebral discitis. Arch Orthop Trauma Surg 131(2):173-178,2011

30. Mastronardi L, Rychlicki F, Tatta C, Morabito L, Agrillo U, Ducati A: Spondylodiscitis after lumbar microdiscectomy: effectiveness of two protocols of intraoperative antibiotic prophylaxis in 1167 cases. Neurosurg Rev 28(4):303-307,2005

31. Mastronardi L, Tatta C: Intraoperative antibiotic prophylaxis in clean spinal surgery: A retrospective analysis in a consecutive series of 973 cases. Surg Neurol 61(2):129-135; discussion 135,2004

32. Meredith DS, Kepler CK, Huang RC, Brause BD, Boachie-Adjei $\mathrm{O}$ : Postoperative infections of the lumbar spine: Presentation and management. Int Orthop 36(2):439-444,2012

33. Meyer B, Schaller K, Rohde V, Hassler W: The C-reactive protein for detection of early infections after lumbar microdiscectomy. Acta Neurochir (Wien) 136(3-4):145-150,1995

34. Michel SC, Pfirrmann CW, Boos N, Hodler J: CT-guided core biopsy of subchondral bone and intervertebral space in suspected spondylodiskitis. AJR Am J Roentgenol 186(4):977980,2006
35. Neumayer F, Kosmopoulos V, Schizas C: Management of a post-operative multi-resistant infectious spondylitis associated with a kyphotic deformity. Acta Orthop Belg 75(4):566-570,2009

36. Ozalay M, Sahin O, Derincek A, Onay U, Turunc T, Uysal M: Nontuberculous thoracic and lumbar spondylodiscitis: Singlestage anterior debridement and reconstruction, combined with posterior instrumentation and grafting. Acta Orthop Belg 76(1):100-106,2010

37. Postacchini F, Cinotti G: Postoperative lumbar discitis. Eur Spine J 1(4):226-230,1993

38. Puranen J, Makela J, Lahde S: Postoperative intervertebral discitis. Acta Orthop Scand 55(4):461-465,1984

39. Rawlings CE 3rd, Wilkins RH, Gallis HA, Goldner JL, Francis R: Postoperative intervertebral disc space infection. Neurosurgery 13(4):371-376,1983

40. Robinson Y, Tschoeke SK, Kayser R, Boehm H, Heyde CE: Reconstruction of large defects in vertebral osteomyelitis with expandable titanium cages. Int Orthop 33(3):745749,2009

41. Rohde V, Meyer B, Schaller C, Hassler WE: Spondylodiscitis after lumbar discectomy. Incidence and a proposal for prophylaxis. Spine (Phila Pa 1976) 23(5):615-620,1998

42. Stosic-Opincal T, Peric V, Grujicic D, Gavrilovic S, Golubicic I: The role of magnetic resonance imaging in the diagnosis of postoperative spondylodiscitis. Vojnosanit Pregl 61(5):479483,2004

43. Sundararaj GD, Babu N, Amritanand R, Venkatesh K, Nithyananth $M$, Cherian VM, Lee VN: Treatment of haematogenous pyogenic vertebral osteomyelitis by singlestage anterior debridement, grafting of the defect and posterior instrumentation. J Bone Joint Surg Br 89(9):12011205,2007

44. Valancius K, Hansen ES, Hoy K, Helmig P, Niedermann B, Bunger $\mathrm{C}$ : Failure modes in conservative and surgical management of infectious spondylodiscitis. Eur Spine J 22(8):1837-1844, 2013

45. Wang X, Zhou J, Zhang C, Liu Z: Single-stage anterior debridement and fusion with autografting and internal fixation for pyogenic lumbar spondylodiscitis. Arch Orthop Trauma Surg 132(4):487-493,2012

46. Yadav YR, Parihar V, Namdev H, Agarwal M, Bhatele PR: Endoscopic interlaminar management of lumbar disc disease. J Neurol Surg A Cent Eur Neurosurg 74(2):77-81,2013

47. Yang $H$, Wang $R$, Luo T, Ouyang Y, Lv F, Xia L, Wang C: MRI manifestations and differentiated diagnosis of postoperative spinal complications. J Huazhong Univ Sci Technolog Med Sci 29(4):522-526,2009

48. Zhang L, Cai WH, Huang B, Chen LW, Zhang N, Ni B: Singlestage posterior debridement and single-level instrumented fusion for spontaneous infectious spondylodiscitis of the lumbar spine. Acta Orthop Belg 77(6):816-822,2011

49. Zink PM, Frank AM, Trappe AE: Prophylaxis of postoperative lumbar spondylodiscitis. Neurosurg Rev 12(4):297-303,1989 